\title{
Production, Purification, and Characterization of Polygalacturonase from Rhizomucor pusillus Isolated from Decomposting Orange Peels
}

\author{
Mohd. Asif Siddiqui, ${ }^{1}$ Veena Pande, ${ }^{1}$ and Mohammad Arif ${ }^{2}$ \\ ${ }^{1}$ Department of Biotechnology, Kumaun University, Campus Bhimtal, Nainital 263136, India \\ ${ }^{2}$ Defence Institute of Bio-Energy Research, Nainital, Haldwani 263139, India \\ Correspondence should be addressed to Mohd. Asif Siddiqui, asifsiddiqui82@gmail.com
}

Received 11 August 2012; Revised 19 September 2012; Accepted 21 September 2012

Academic Editor: Denise M. Guimarães Freire

Copyright ( 2012 Mohd. Asif Siddiqui et al. This is an open access article distributed under the Creative Commons Attribution License, which permits unrestricted use, distribution, and reproduction in any medium, provided the original work is properly cited.

\begin{abstract}
A thermophilic fungal strain producing polygalacturonase was isolated after primary screening of 40 different isolates. The fungus was identified as Rhizomucor pusilis by Microbial Type Culture Collection (MTCC), Chandigarh, India. An extracellular polygalacturonase (PGase) from R. pusilis was purified to homogeneity by two chromatographic steps using Sephadex G-200 and Sephacryl S-100. The purified enzyme was a monomer with a molecular weight of $32 \mathrm{kDa}$. The PGase was optimally active at $55^{\circ} \mathrm{C}$ and at $\mathrm{pH}$ 5.0. It was stable up to $50^{\circ} \mathrm{C}$ for $120 \mathrm{~min}$ of incubation and $\mathrm{pH}$ condition between 4.0 and 5.0. The stability of PGase decreases rapidly above $60^{\circ} \mathrm{C}$ and above $\mathrm{pH}$ 5.0. The apparent $K_{m}$ and $V_{\max }$ values were $0.22 \mathrm{mg} / \mathrm{mL}$ and $4.34 \mathrm{U} / \mathrm{mL}$, respectively. It was the first time that a polygalacturonase enzyme was purified in this species. It would be worthwhile to exploit this strain for polygalacturonase production. Polygalacturonase from this strain can be recommended for the commercial production because of its constitutive and less catabolically repressive nature, thermostability, wide range of $\mathrm{pH}$, and lower $K_{m}$ properties. However, scale-up studies are needed for the better output for commercial production.
\end{abstract}

\section{Introduction}

Pectin substances constitute a complex linear backbone comprised of $\alpha$-1, 4-linked d-galacturonic acid residues which may be methylated and substituted with l-rhamnose, arabinose, galactose, and xylose [1-3]. Because of the large variety of pectins in plant material, they endowed with many pectinolytic enzyme systems which can degrade them [4]. The hydrolysis of pectin backbone is obtained by the synergistic action of several enzymes, including pectin methylesterase (EC. 3.1.11.1), endopolygalacturonase (EC. 3.2.1.15), exopolygalacturonase (EC. 3.2.1.67), pectate lyase (EC. 4.2.2.2), exo-pectate lyase (EC. 4.2.2.9), and endopectin lyase (4.2.2.10) [5, 6].

Pectinolytic enzymes are of prime importance for plants as they help in cell-wall extension and softening of some plant tissues during maturation and storage $[7,8]$. They also aid in maintaining ecological balance by causing decomposition and recycling of waste plant materials. Plant pathogenicity and spoilage of fruits and vegetables by rotting are some other major manifestations of pectinolytic enzymes $[9,10]$. They have been used in many industrial and biotechnological processes, such as textile and plant fiber processing, coffee and tea fermentation, oil extraction, treatment of industrial wastewater containing pertinacious material, purification of plant viruses, and paper making [11]. Commercial enzyme preparations used in processing of food, traditionally, comprising of the mixtures of polygalacturonase, pectate lyase, and pectin esterase, are almost exclusively derived from fungal species, especially Mucor and Aspergillus [12]. Preparations containing pectin-degrading enzymes used in the food industry are of fungal origin because fungi are potent producers of pectic enzymes and the optimal $\mathrm{pH}$ of fungal enzymes is very close to the $\mathrm{pH}$ of many fruit juices, which range from $\mathrm{pH} 3.0$ to 5.5 [13]. Due to the potential and wide applications of pectinases, there is 
a need to highlight recent developments on several aspects related to their production.

Higher cost of the production is perhaps the major constraint in commercialization of new sources of enzymes. Though, using high yielding strains, optimal fermentation conditions, and efficient enzyme recovery procedures can reduce the cost. In addition, technical constraint includes supply of cheap and pure raw materials and difficulties in achieving high operational stabilities, particularly to temperature and $\mathrm{pH}$. Literature highlighting the optimization, biochemical characterization, genetics, and strain improvement studies of pectinases from mesophilic fungi is available [14-18]. However, there are few studies where stable pectinases have been reported from thermophilic fungi. Therefore in the present paper, we describe the isolation of pectinase producing fungi, purification, and characterization of polygalacturonase (PG) with appreciable activity and temperature and $\mathrm{pH}$ stability.

\section{Material and Methods}

2.1. Organism and Culture Conditions. Pectinase producing fungi were isolated from various soil, decayed fruits, and other vegetables collected from different fruits markets of western Uttar Pradesh by using modified pectin agar medium of following composition (g/L, $\mathrm{wt} / \mathrm{vol}$.) [19]: Pectin-10.0, Sucrose-10.0, Tryptone-3.0, Yeast extract-2.0, $\mathrm{KCl}-0.5, \mathrm{MgSO}_{4} \cdot 7 \mathrm{H}_{2} \mathrm{O}-0.5, \mathrm{MnSO}_{4} \cdot 5 \mathrm{H}_{2} \mathrm{O}-0.01$, $\left(\mathrm{NH}_{4}\right)_{2} \mathrm{SO}_{4}-2.0$, Agar-20.00 supplemented with mineral salt solution of composition $\mathrm{g} / 100 \mathrm{~mL} \mathrm{CuSO}{ }_{4} \cdot 5 \mathrm{H}_{2} \mathrm{O}-0.04$, $\mathrm{FeSO}_{4}-0.08, \mathrm{Na}_{2} \mathrm{MoO}_{4}-0.08, \mathrm{ZnSO}_{4}-0.8, \mathrm{Na}_{2} \mathrm{~B}_{4} \mathrm{O}_{7}-0.004$, and $\mathrm{MnSO}_{4}-0.008$. To the above medium distilled water was added to make 1 liter solution. The $\mathrm{pH}$ of the media was adjusted to $5.5-6.0$ by using $1.0 \mathrm{~N} \mathrm{HCl} / 1.0 \mathrm{~N} \mathrm{NaOH}$. The salt solution with pectin, and agar were autoclaved separately. The sterilization was done at $121^{\circ} \mathrm{C}(10 \mathrm{lbs})$ for 15 minutes to avoid pectin degradation. After sterilization the pectin media and agar were mixed aseptically. Ampicillin $(100 \mathrm{mg} / \mathrm{mL})$ was also added to restrict bacterial growth. The inoculated plates were incubated at $50^{\circ} \mathrm{C}$ for $5-7$ days. The cultures were further screened by subculturing on YPSS (Yeast soluble starch agar) medium having the following composition (g/L, wt/vol.): Pectin-15, Yeast extract-0.4, $\mathrm{K}_{2} \mathrm{HPO}_{4}-0.23$, $\mathrm{KH}_{2} \mathrm{PO}_{4}-0.2, \mathrm{MgSO}_{4} \cdot 7 \mathrm{H}_{2} \mathrm{O}-0.05$, and Citric acid-0.052. The $\mathrm{pH}$ of the media was adjusted to 5.5 by using $1.0 \mathrm{~N} \mathrm{HCl} / 1.0 \mathrm{~N}$ $\mathrm{NaOH}$. Pectin utilization was detected by flooding the culture plates with freshly prepared $1 \%$ Cetrimide solution and allowed to stand for 20-30 minutes. A clear zone around the colonies against a white background (of the medium) indicates the ability of an isolate to produce pectinase. Based on screening, the isolated fungi were identified up to genus level by examining the morphological characters following Dubey and Maheshwari [20]. Highest pectinase producer isolate was selected for further studies and the culture was sent to MTCC, Chandigarh, for species identification.

2.2. Medium for Solid-State Fermentation (SSF) and Enzyme Production. The solid state cultivation was carried out in $250 \mathrm{~mL}$ Erlenmeyer flasks containing $15 \mathrm{~g}$ of basal medium (Pectin-0.5, Urea-0.15, Sucrose-1.57, $\left(\mathrm{NH}_{4}\right)_{2} \mathrm{SO}_{4}$ $0.68, \mathrm{KH}_{2} \mathrm{PO}_{4}-0.33, \mathrm{FeSO}_{4}-0.15$, and Sugarcane bagasse11.6). The flasks were inoculated with $2 \mathrm{~mL}$ spore suspension containing $10^{6}$ spores $\mathrm{mL}^{-1}$, which was obtained from a fiveday agar slant. Final moisture was adjusted to $70 \%$. The $\mathrm{pH}$ of the media was adjusted to $5.5-6.0$ by using $1.0 \mathrm{~N}$ $\mathrm{HCl} / 1.0 \mathrm{~N} \mathrm{NaOH}[21]$. The cultivation was carried out at $50^{\circ} \mathrm{C}$ for 4-5 days. The fermented media were extracted with $30 \mathrm{~mL}$ of distilled water. The flasks were shaken vigorously and kept for one hour and filtered through cheese cloth. The crude enzyme was extracted by adding $100 \mathrm{~mL}$ of citrate buffer $(0.1 \mathrm{M}, \mathrm{pH} 5.0)$ to each flask. The extract was centrifuged at $10,000 \mathrm{rpm}$ for $15 \mathrm{~min}$ at $4{ }^{\circ} \mathrm{C}$ and the supernatant was filtered through Whatman No. 1 filter paper to remove spores completely.

2.3. Enzyme Purification Procedure. The filtrate was centrifuged at 10,000 rpm for $20 \mathrm{~min}$ at refrigerated condition. Solid ammonium sulfate was slowly added to the supernatant of crude enzyme preparation so as to reach $20 \%$ saturation. Addition of ammonium sulfate was carried out with continuous stirring in an ice bath, and then it was kept at $4^{\circ} \mathrm{C}$ for overnight. The precipitated protein was removed by centrifugation at $10,000 \mathrm{rpm}$ for $30 \mathrm{~min}$ at $4^{\circ} \mathrm{C}$. Ammonium sulfate was added to the supernatant to $80 \%$ saturation. The precipitated protein was again separated by centrifugation at $10,000 \mathrm{rpm}$ for $30 \mathrm{~min}$ at $4^{\circ} \mathrm{C}$. The precipitated protein was dissolved in sodium acetate buffer $(0.1 \mathrm{M} ; \mathrm{pH} 5.0)$. The crude enzyme was loaded on a Sephadex G-200 column (1 $\times 50 \mathrm{~cm})$ preequilibrated with sodium acetate buffer $(0.1 \mathrm{M}$; $\mathrm{pH}$ 5.0). Fractions in $3 \mathrm{~mL}$ volume were collected at a flow rate of $24 \mathrm{~mL} /$ hour. The eluted fractions were monitored at $280 \mathrm{~nm}$ for protein and assayed for enzyme activity. Fraction with highest polygalacturonase activity was loaded on Sephacryl S- 100 column $(1.6 \mathrm{~cm} \times 60 \mathrm{~cm})$ preequilibrated with same at a flow rate of $20 \mathrm{~mL} /$ hour. Fractions of $1.5 \mathrm{~mL}$ were collected and monitored for proteins and polygalacturonase activity.

2.4. Enzyme Assay. The PGase activity was assayed by estimating the amount of reducing sugar released under assay conditions. Polygalacturonase activity was measured by determining the amount of reducing groups released according to the method described by Nelson [22] and modified by Somogyi [23]. The substrate used for assay was $1 \%$ PGA (polygalacturonic acid), that is, $1.0 \mathrm{~g}$ of PGA in $100 \mathrm{~mL}$ of $0.1 \mathrm{M}$ citrate buffer, $\mathrm{pH}$ 5.0. The assay mixture was prepared with the following components: $0.2 \mathrm{~mL}$ enzyme, $0.1 \mathrm{~mL}$ of $0.1 \mathrm{M} \mathrm{CaCl}$, and $0.5 \mathrm{~mL}$ of $1 \%$ solution of polygalacturonic acid (PGA). Blank was prepared for each sample by boiling the reaction mixture before the addition of substrate. Tubes were incubated at $37^{\circ} \mathrm{C}$ for one hour. The reaction was stopped by heating at $100^{\circ} \mathrm{C}$ for 3 minutes. $0.5 \mathrm{~mL}$ of the solution mixture was taken and analyzed for reducing sugars by Nelson-Somogyi method. Final volume was made up to $2 \mathrm{~mL}$ in both sample and standard tubes with distilled water. $1.0 \mathrm{~mL}$ of alkaline copper tartrate was added and kept for 10 minutes. Tubes were cooled and $1.0 \mathrm{~mL}$ of arsenomolybdate reagent was added to each of 
the tubes. Final volume was made up to $10 \mathrm{~mL}$ volume in each tube with distilled water. The absorbance of blue color was recorded at $620 \mathrm{~nm}$ after 10 minutes.

The amount of galacturonic acid released per $\mathrm{mL}$ per minute was calculated from standard curve of galacturonic acid. One unit of enzyme activity is defined as the enzyme that releases $1 \mu \mathrm{mol} \mathrm{mL} L^{-1} \mathrm{~min}^{-1}$ galacturonic acid under standard assay conditions.

2.5. Protein Determination. The protein content of the enzyme solution is estimated by the method developed by Lowry et al. [24] with Bovine serum albumin (BSA) as standard.

2.6. Electrophoresis. The purified enzyme was subjected to electrophoretic studies to determine molecular weight. SDS PAGE $(12.5 \%)$ was conducted by using a slab gel apparatus with notched glass plate system [25]. Gels of $1.5 \mathrm{~mm}$ thickness was prepared using spacers of the same size. The wide range protein molecular weight marker was used for molecular weight determination of proteins. It contains myosin $(205 \mathrm{kDa})$, Phosphorylase b $(97.4 \mathrm{kDa})$, Bovine Serum albumin $(66 \mathrm{kDa})$, Ovalbumin $(43 \mathrm{kDa})$, Carbonic anhydrase $(29 \mathrm{kDa})$, Soybean Trypsin Inhibitor $(20.1 \mathrm{kDa})$, and Lysozyme $(14.3 \mathrm{kDa})$. The gel was stained by coomassie blue prepared in 3.5\% perchloric acid. After staining gel was washed and destained with acetic acid solution (7.5\%) several times until band becomes visible and the background becomes clear.

2.7. Characterization of PGase. The substrate specificity of the purified enzyme was determined by using various substrates in the reaction mixture for enzyme assay. The various substrates used were polygalacturonic acid, pectin, xylan, galactose, and cellulose at $0.1 \%(\mathrm{w} / \mathrm{v})$ [18].

The optimum temperature was estimated by performing the standard assay within the temperature range of $30-80^{\circ} \mathrm{C}$. Incubating the enzyme for 4 hours at temperature from $30-80^{\circ} \mathrm{C}$ in assay buffer and then measuring the remaining activity by standard assay determined the inactivation temperature. The optimal $\mathrm{pH}$ for PGase activity was evaluated by varying the $\mathrm{pH}$ of the reaction mixture between 3.0 and 9.0 at increments of 1.0. Activity was then assessed under standard conditions. The effect of substrate concentration on PGase activity was assayed in standard assay by using PGA in various concentrations $(0.1-1.0 \mathrm{mg})$ and $K_{m}$ and $V_{\max }$ were evaluated.

\section{Results and Discussion}

3.1. Isolation and Selection of Isolate. Thermophilic fungal strains isolated from various precollected samples from different fruits markets of western Uttar Pradesh were purified and their cultural and morphological characteristics were examined according to the method described by Dubey and Maheshwari [20]. A total of 40 fungal strains were isolated from 15 different soil, decayed fruits, and other vegetables samples. Different species of Mucor, Aspergillus,
TABle 1: Polygalacturonase activity of crude enzyme extract of different isolates.

\begin{tabular}{lcc}
\hline S. no. & Isolate no. & PG activity $(\mathrm{U} / \mathrm{mL})$ \\
\hline 1 & Isolate 1 & 12.78 \\
2 & Isolate 2 & 6.13 \\
3 & Isolate 3 & 19.27 \\
4 & Isolate 4 & 1.92 \\
5 & Isolate 5 & 7.81 \\
6 & Isolate 6 & 0.76 \\
7 & Isolate 7 & 32.57 \\
8 & Isolate 8 & 3.45 \\
9 & Isolate 9 & 9.67 \\
10 & Isolate 10 & 1.08 \\
11 & Isolate 11 & 14.10 \\
12 & Isolate 12 & 23.42 \\
\hline
\end{tabular}

Penicillium, Rhizopus, and Trichoderma were isolated. Similar results were also reported by different coworkers: Mucor [26], Aspergillus [27], Penicillium [28], Rhizopus [29], and Tricoderma [30].

High pectinase producing strains were further screened semiquantitatively by plate assay method. Twelve different isolates were further screened by solid state fermentation (Figure 1). The results indicate that isolate 7 shows maximum activity for polygalacturonase (Table 1). The isolate was further identified as Rhizomucor pusillus by Microbial Type Culture Collection (MTCC), Chandigarh, India.

3.2. Production and Detection of PGase. The production of PGase by $R$. pusillus was induced by pectin (pure) $(1.5 \% \mathrm{w} / \mathrm{v})$ as carbon source, urea $(0.3 \% \mathrm{w} / \mathrm{v})$ as nitrogen source, and $\mathrm{MnSO}_{4}(0.2 \% \mathrm{w} / \mathrm{v})$ as mineral supplement at $45^{\circ} \mathrm{C}$. The maximum reported polygalacturonase activity of Mucor genevensis is $5.0 \mathrm{U} / \mathrm{mL}$ [26], Mucor sp. 7 is $15.2 \mathrm{U} / \mathrm{mL}[31$ ], Penicillium viridicatum is $18 \mathrm{U} / \mathrm{mL}$ [32], and Mucor circinelloides is $9.15 \mathrm{U} / \mathrm{mL}$ [18]. In the present study polygalacturonase activity was $32.57 \mathrm{U} / \mathrm{mL}$. No report on polygalacturonase production from Rhizomucor pusillus is available in the literature. However it is evident from this work that this strain is a hyperproductive one and is suitable for further studies.

The crude enzyme was extracted from fermented media by a process of filtration and centrifugation to remove mycelia and other media components; the crude was concentrated to $150 \mathrm{~mL}$. The crude extract contains evaluated protein and specific activity of $6.38 \mathrm{mg}$ and $4.97 \mathrm{U} / \mathrm{mg}$, respectively.

3.3. Purification of PGase. The purification of the PGase activity was carried out by two chromatographic steps.

First, $6.38 \mathrm{mg}$ of protein from CE $(150 \mathrm{~mL})$ with a total activity of 31.74 U were loaded on a Sephadex G-200 column. The eluted fractions with PGase activity were identified and pooled, concentrated to $1 \mathrm{~mL}$, and applied on a Sephacryl S-100 column eluted with sodium acetate buffer $(0.1 \mathrm{M}, \mathrm{pH}$ 5.0). PGase activity was detected in fractions eluted between 


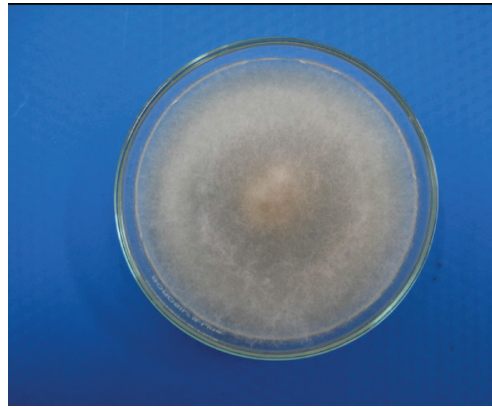

Isolate 1: tomato

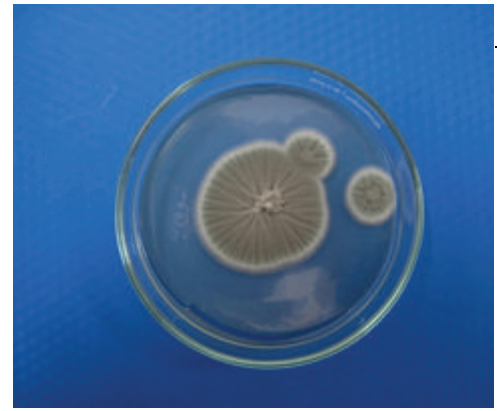

Isolate 4: soil

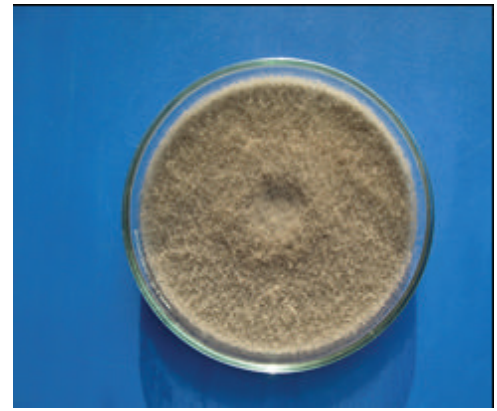

Isolate 7: orange

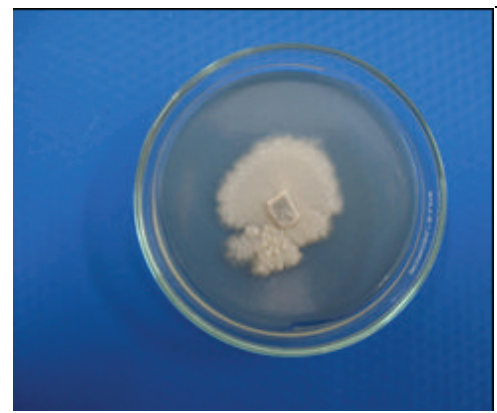

Isolate 10: soil

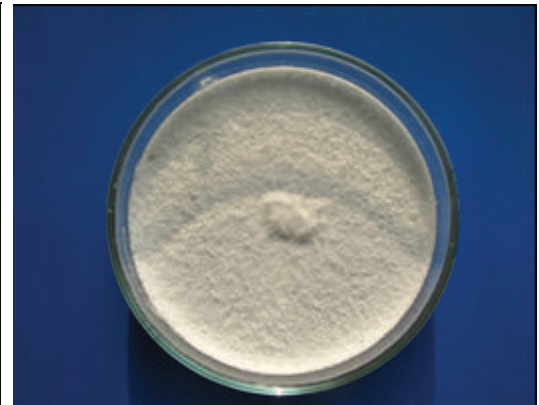

Isolate 2: pineapple

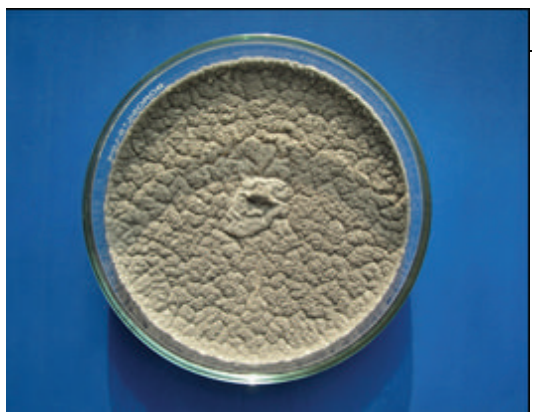

Isolate 5: orange

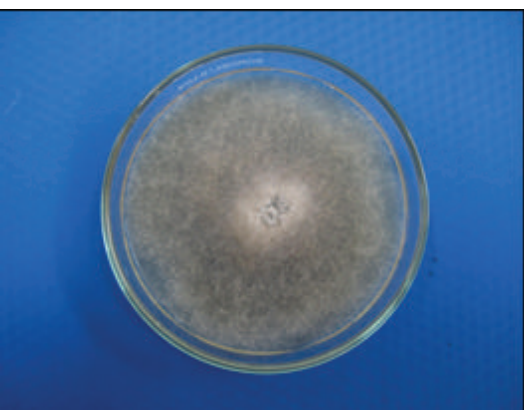

Isolate 8: apple

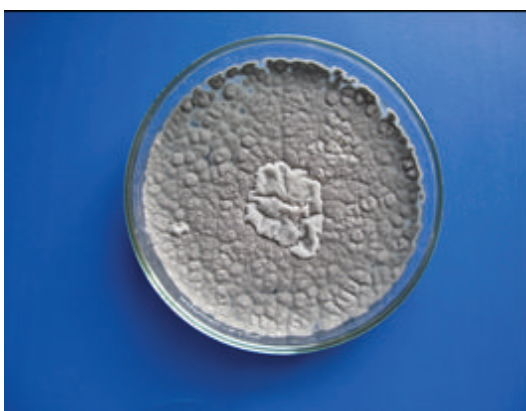

Isolate 11: pineapple

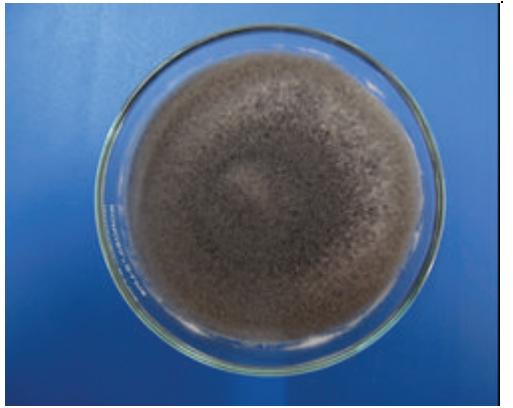

Isolate 3: sweet lime

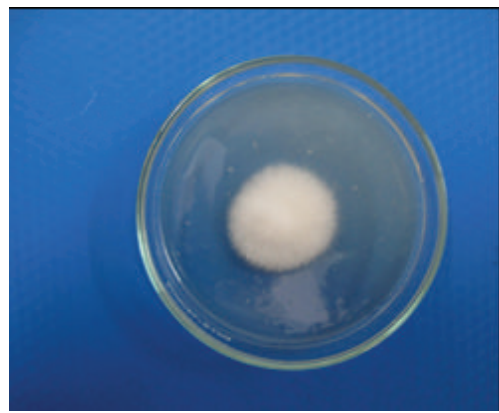

Isolate 6: brinjal

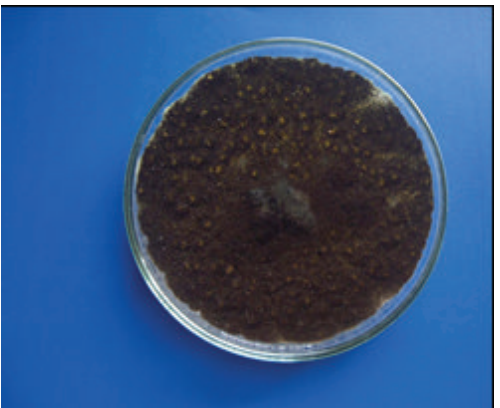

Isolate 9: pomegranate

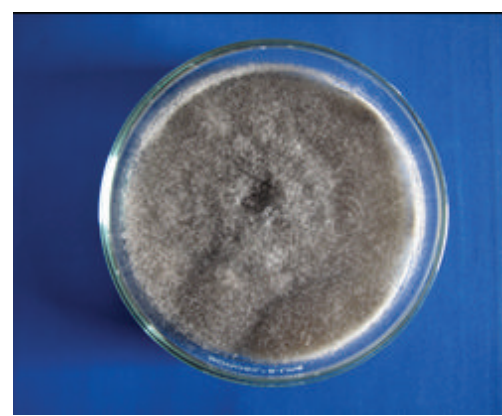

Isolate 12: guava

FIGURE 1: Twelve fungal isolates selected for further study on the basis of screening (5th day old culture).

54 and $75 \mathrm{~mL}$. These last were pooled and concentrated to $1 \mathrm{~mL}$. Table 2 summarizes the steps involved in this purification as well as the specific activity, fold purification, and yield. Final specific activity of the purified PGase was $61.35 \mathrm{U} / \mathrm{mg}$. Final fold purification and yield were 12.34 and 27.06, respectively, in standard conditions. The previous works showed a marked variation in the cases of purification factor and yield. Esquivel and Voget [33] reported more than 400 fold purification and $40 \%$ yield for A. kawachii IFO 4033. Mohamed et al. [34] reported 13-fold purification and 55\% yield for Tricoderma harzianum. Celestino et al. [35] reported 9.37 -fold purification and $60.62 \%$ yield for Acrophialophora nainiana. Saad et al. [36] reported 85-fold purification and $1.87 \%$ yield for Mucor rouxii NRRL 1894. Thakur et al. [18] reported 13.3-fold purification and 3.4\% yield for Mucor circinelloides. These factors mainly depend 


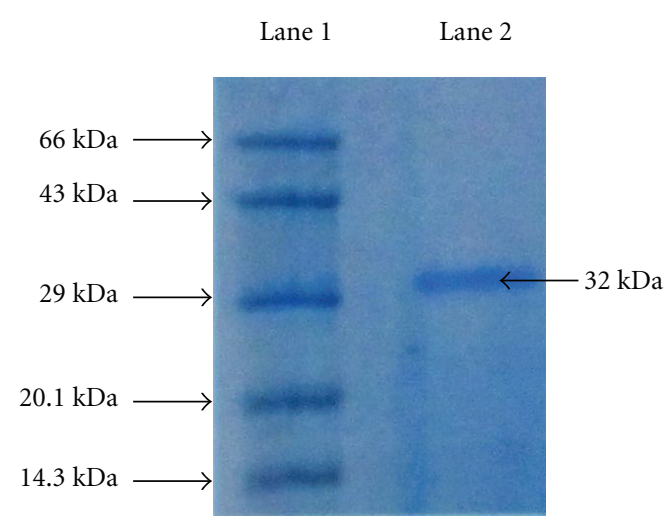

Lane 1: Bangalore Genei protein marker $(\mathrm{kDa})$

Lane 2: purified enzyme

FIgURE 2: SDS PAGE of purified polygalacturonase from Rhizomucor pusillus. Molecular weights markers: (1) Bovine Serum Albumin—66 kDa, (2) Ovalbumin—43.0 kDa, (3) Carbonic anhydrase-29.0 kDa, (4) Soybean Trypsin Inhibitor-20.1 kDa, (5) Lysozyme-14.3 kDa.

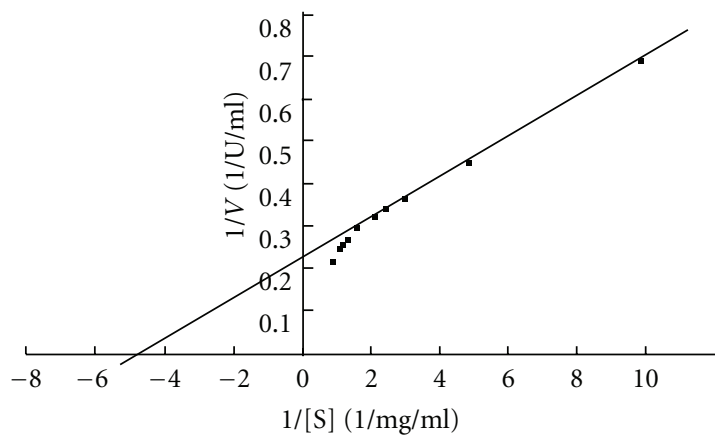

FIGURE 3: Lineweaver-Burk plot for polygalacturonase from Rhizomucor pusillus.

not only on the strain but also the methods adopted for purification. Generally an increase in fold purification results in a gradual decrease in yield.

The purified PGase was homogenous as judged by electrophoresis gel (Figure 2), where one protein band was detected after step 2. By SDS-PAGE, a molecular weight of $32 \mathrm{kDa}$ was determined. Similar observations were made in Geotrichum candidum-34.5 kDa [37], Rhizopus sp. LKN-38.5 kDa [38], Verticillium albo-atrum-37 kDa [39], Fusarium solani-38 kDa [40], Fusarium moniliforme$30.6 \mathrm{kDa}$ [41], Trichoderma harzianum-31 kDa [42], and Acrophialophora nainiana-35.5 kDa [35].

3.4. Characterization of PGase. The maximum PGases specificity was observed when polygalacturonic acid was used as substrate. Assuming it as $100 \%$, almost half (57\%) activity was expressed with pectin and only $37.8 \%$ activity was expressed with cellulose (Table 3). Previous works supporting the present study are that of Kaji and Okada [43], Kumari and Sirsi [44], Gillespie et al. [45], Shanley et al. [46], Singh

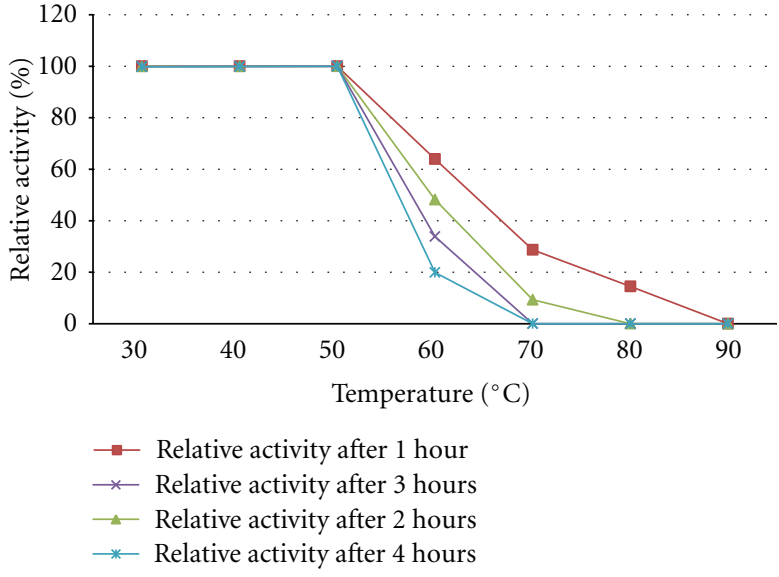

FIGURE 4: Effect of temperature on polygalacturonase stability from Rhizomucor pusillus.

and Rao [47], Mohamed et al. [34, 42], Esquivel and Voget [33], and Saad et al. [36].

The $K_{m}$ and $V_{\max }$ values of PGases of $R$. pusillus are $0.22 \mathrm{mg} / \mathrm{mL}$ and $4.34 \mathrm{U} / \mathrm{mL}$, respectively, by plotting the Lineweaver Burk plot (Figure 3). Bonnin et al. [48] reported a $K_{m}$ of $0.071 \mathrm{nmol} / \mathrm{mL}$ and $V_{\max }$ of $432 \mathrm{nkat} / \mathrm{mg}$ of endoPG for Fusarium moniliforme. Saad et al. [36] reported a $K_{m}$ of $1.88 \mathrm{mg} / \mathrm{mL}$ and $V_{\max }$ of $0.045 \mathrm{~mole} / \mathrm{mL} / \mathrm{min}$ for Mucor rouxii. Thakur et al. [18] reported a $K_{m}$ of $2.2 \mathrm{mM}$ and $V_{\max }$ of $4.81 \mathrm{IU} / \mathrm{mL}$ for Mucor circinelloides. From these studies it is evident that the kinetic properties of PG vary with the source of the enzyme. But in most cases the $K_{m}$ value is low, which agrees with the result of the present study.

The optimum temperature of the purified polygalacturonase from $R$. pusillus was $55^{\circ} \mathrm{C}$ (Table 4 ). The enzyme was stable at $50^{\circ} \mathrm{C}$. After two hours the PG activity was only 48.2 and $9.30 \%$ at 60 and $70^{\circ} \mathrm{C}$, respectively, and then the enzyme became suddenly inactive. From $80^{\circ} \mathrm{C}$ onwards the enzyme activity was lost during the first hour itself (Figure 4). This agreed with the earlier works of Martins et al. [49] who reported temperature optima for Thermoascus aurantiacus at $60^{\circ} \mathrm{C}$; the enzyme was stable at $60^{\circ} \mathrm{C}$ for 1 hour. Kaur et al. [50] reported temperature optima for Sporotrichum thermophile apinis at $55^{\circ} \mathrm{C}$ and the enzyme was stable up to 4 th hour at $65^{\circ} \mathrm{C}$. Thakur et al. [18] reported temperature optima for Mucor circinelloides at $42^{\circ} \mathrm{C}$ and the enzyme was stable up to 4 th hour at $42^{\circ} \mathrm{C}$. Andrade et al. [51] reported the optimum temperature for polygalacturonase enzyme between $60-70^{\circ} \mathrm{C}$ and the enzyme retained about 82 and $63 \%$ of its activity at 60 and $70^{\circ} \mathrm{C}$, respectively, after 2 hours of incubation.

The $\mathrm{pH}$ optima of the purified polygalacturonase from $R$. pusillus was 5.0 (Table 5). The enzyme was stable at $\mathrm{pH}$ conditions 4.0-5.0. Above pH 5.0 enzyme stability began to decrease. At $\mathrm{pH} 8.0$ after 4 th hour the residual activity was $40.21 \%$ of that of the control. No activity was determined at $\mathrm{pH} 9.0$ at 4th hour (Figure 5). Previous works supporting the present study are reported for Aspergillus sojae-5.0 [52], Mucor rouxii-4.5 [36], Mucor circinelloides-5.5 [18], 
TABLe 2: Purification of polygalacturonase from Rhizomucor pusilis.

\begin{tabular}{|c|c|c|c|c|c|}
\hline Purification step & Total activity $(\mathrm{U} / \mathrm{mL})$ & Total protein $(\mathrm{mg})$ & Specific activity (U/mg) & Fold purification & Yield (\%) \\
\hline Crude preparation & 31.74 & 6.38 & 4.97 & 1 & 100 \\
\hline Sephadex G-200 & 13.23 & 0.42 & 31.50 & 6.33 & 41.68 \\
\hline Sephacryl S-100 & 8.59 & 0.14 & 61.35 & 12.34 & 27.06 \\
\hline
\end{tabular}

TABLE 3: Substrate specificity of polygalacturonase from Rhizomucor pusilis.

\begin{tabular}{lccc}
\hline S. No. & Substrate $(0.1 \%)$ & $\begin{array}{c}\text { Enzyme } \\
\text { activity }(\mathrm{U} / \mathrm{mL})\end{array}$ & $\begin{array}{c}\text { Relative } \\
\text { activity }(\%)\end{array}$ \\
\hline 1 & Polygalacturonic acid & 8.34 & 100 \\
2 & Pectin & 4.75 & 57 \\
3 & Xylan & 0.92 & 11.0 \\
4 & Galactose & 0.55 & 6.7 \\
5 & Cellulose & 3.15 & 37.8 \\
\hline
\end{tabular}

TABLE 4: Effect of temperature on polygalacturonase activity from Rhizomucor pusilis.

\begin{tabular}{lccc}
\hline S. No. & Temperature $\left({ }^{\circ} \mathrm{C}\right)$ & $\begin{array}{c}\text { Enzyme } \\
\text { activity }(\mathrm{U} / \mathrm{mL})\end{array}$ & $\begin{array}{c}\text { Relative } \\
\text { activity }(\%)\end{array}$ \\
\hline 1 & 30 & 2.27 & 27.04 \\
2 & 35 & 3.18 & 37.92 \\
3 & 40 & 4.34 & 51.62 \\
4 & 45 & 5.59 & 66.50 \\
5 & 50 & 6.88 & 81.91 \\
$\mathbf{6}$ & $\mathbf{5 5}$ & $\mathbf{8 . 4 1}$ & $\mathbf{1 0 0}$ \\
7 & 60 & 4.40 & 52.41 \\
8 & 65 & 2.88 & 34.30 \\
9 & 70 & 1.97 & 23.51 \\
10 & 75 & 1.09 & 13.01 \\
\hline
\end{tabular}

TABLE 5: Effect of $\mathrm{pH}$ on polygalacturonase activity from Rhizomucor pusilis.

\begin{tabular}{lccc}
\hline S. No. & $\mathrm{pH}$ & Enzyme activity $(\mathrm{U} / \mathrm{mL})$ & Relative activity $(\%)$ \\
\hline 1 & 3 & 0.81 & 9.53 \\
2 & 4 & 6.31 & 74.44 \\
3 & 5 & $\mathbf{8 . 4 7}$ & $\mathbf{1 0 0}$ \\
4 & 6 & 4.78 & 56.48 \\
5 & 7 & 2.38 & 28.12 \\
6 & 8 & 2.90 & 34.30 \\
7 & 9 & 0.19 & 2.31 \\
\hline
\end{tabular}

and Cylindrocarpon destructans-5.0 [53]. This is the typical characteristic of fungal PG [54]. In the present study it was observed that the maximum stability of the enzyme was between $\mathrm{pH} 4.0$ and 5.0 followed by a fall in stability at higher $\mathrm{pH}$.

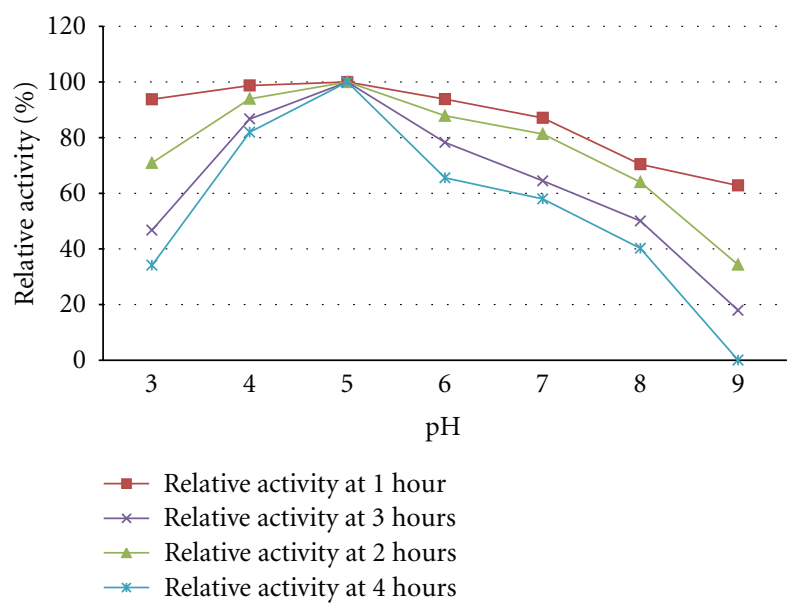

Figure 5: Effect of $\mathrm{pH}$ on polygalacturonase stability from $R h i-$ zomucor pusillus.

\section{References}

[1] R. V. Gadre, G. Van Driessche, J. Van Beeumen, and M. K. Bhat, "Purification, characterisation and mode of action of an endo-polygalacturonase from the psychrophilic fungus Mucor flavus," Enzyme and Microbial Technology, vol. 32, no. 2, pp. 321-330, 2003.

[2] D. R. Kashyap, P. K. Vohra, S. Chopra, and R. Tewari, "Applications of pectinases in the commercial sector: a review," Bioresource Technology, vol. 77, no. 3, pp. 215-227, 2001.

[3] T. Nakagawa, T. Nagaoka, S. Taniguchi, T. Miyaji, and N. Tomizuka, "Isolation and characterization of psychrophilic yeasts producing cold-adapted pectinolytic enzymes," Letters in Applied Microbiology, vol. 38, no. 5, pp. 383-387, 2004.

[4] J. A. E. Bene, J. P. Vincken, and G. J. W. M. Van Alebeek, "Microbial pectinases," in Pectins and Their Manipulation, G. B. Seymour and J. P. Knox, Eds., pp. 174-221, Blackwell Publishing, Oxford, UK, 2002.

[5] S. N. Gummadi and T. Panda, "Purification and biochemical properties of microbial pectinases-a review," Process Biochemistry, vol. 38, no. 7, pp. 987-996, 2003.

[6] M. M. C. N. Soares, R. Da Silva, E. C. Carmona, and E. Gomes, "Pectinolytic enzyme production by Bacillus species and their potential application on juice extraction," World Journal of Microbiology and Biotechnology, vol. 17, no. 1, pp. 79-82, 2001.

[7] G. Aguilar and C. Huitron, "Constitutive exo-pectin produced by Aspergillus sp. CH-Y-1043 on different carbon source," Biotechnology Letters, vol. 12, no. 9, pp. 655-660, 1990.

[8] T. Sakai, "Degradation of pectins," in Microbial Degradation of Natural Products, G. Winkelmann, Ed., pp. 57-81, VCH, Weinheim, Germany, 1992.

[9] L. Fraissinet-Tachet and M. Fevre, "Regulation by galacturonic acid of pectinolytic enzyme production by Sclerotinia 
sclerotiorum," Current Microbiology, vol. 33, no. 1, pp. 49-53, 1996.

[10] S. A. Singh, M. Ramakrishna, and A. G. Appu Rao, "Optimisation of downstream processing parameters for the recovery of pectinase from the fermented bran of Aspergillus carbonarius," Process Biochemistry, vol. 35, no. 3-4, pp. 411-417, 1999.

[11] G. Hoondal, R. Tiwari, R. Tewari, N. Dahiya, and Q. Beg, "Microbial alkaline pectinases and their industrial applications: a review," Applied Microbiology and Biotechnology, vol. 59, no. 4-5, pp. 409-418, 2002.

[12] C. Lang and H. Dornenburg, "Perspectives in the biological function and the technological application of polygalacturonases," Applied Microbiology and Biotechnology, vol. 53, no. 4, pp. 366-375, 2000.

[13] S. Ueda, F. Yusaku, and J. Y. Lim, "Production and some properties of pectic enzymes from Aspergillus oryzae A-3," Journal of Applied Biochemistry, vol. 4, pp. 524-532, 1982.

[14] C. Fanelli, M. G. Cacace, and F. Cervone, "Purification and properties of two polygalacturonases from Trichoderma koningii," Journal of General Microbiology, vol. 104, no. 2, pp. 305-309, 1978.

[15] J. P. Bartha, D. Cantenys, and A. Touze, "Purification and characterization of two polygalacturonases secreted by Colletotrichum lindemuthanum," Phytopathologische Zeitschrift, vol. 180, pp. 162-165, 1981.

[16] P. Marciano, P. Di Lenna, and P. Magro, "Polygalacturonase isoenzymes produced by Sclerotinia sclerotiorum in vivo and in vitro," Physiological Plant Pathology, vol. 20, no. 2, pp. 201212, 1982

[17] L. Marcus, I. Barash, B. Sneh, Y. Koltin, and A. Finkler, "Purification and characterization of pectolytic enzymes produced by virulent and hypovirulent isolates of Rhizocotonia solaniss," Physiological and Molecular Plant Pathology, vol. 29, pp. 325336, 1986.

[18] A. Thakur, R. Pahwa, S. Singh, and R. Gupta, "Production, purification, and characterization of polygalacturonase from Mucor circinelloides ITCC 6025," Enzyme Research, vol. 2010, Article ID 170549, 7 pages, 2010.

[19] S. Singh and D. K. Sandhu, "Thermophilous fungi in Port Blair soils," Canadian Journal of Botany, vol. 64, no. 5, pp. 1018 1026, 1986.

[20] R. C. Dubey and D. K. Maheshwari, Practical Microbiology, S. Chand \& Co., New Delhi, India, 2nd edition, 2006.

[21] M. E. Acuna-Arguelles, M. Gutierrez-Rojas, G. ViniegraGonzalez, and E. Favela-Torres, "Production and properties of three pectinolytic activities produced by Aspergillus niger in submerged and solid-state fermentation," Applied Microbiology and Biotechnology, vol. 43, no. 5, pp. 808-814, 1995.

[22] N. Nelson, "A photometric adaptation of the Somogyi method for the determination of glucose," The Journal of Biological Chemistry, vol. 153, pp. 375-380, 1944.

[23] M. Somogyi, "Notes on sugar determination," The Journal of Biological Chemistry, vol. 195, no. 1, pp. 19-23, 1952.

[24] O. H. Lowry, N. J. Rosebrough, A. L. Farr, and R. J. Randall, "Protein measurement with the folin phenol reagent," The Journal of Biological Chemistry, vol. 193, no. 1, pp. 265-275, 1951.

[25] U. K. Laemmli, "Cleavage of structural proteins during the assembly of the head of bacteriophage T4," Nature, vol. 227, no. 5259, pp. 680-685, 1970.

[26] M. H. Alves, G. M. Campos-Takaki, A. L. Figueiredo Porto, and A. I. Milanez, "Screening of Mucor spp. for the production of amylase, lipase, polygalacturonase and protease," Brazilian Journal of Microbiology, vol. 33, no. 4, pp. 325-330, 2002.

[27] P. J. Mill, "The pectic enzymes of Aspergillus niger. A mercuryactivated exopolygalacturonase," Biochemical Journal, vol. 99, no. 3, pp. 557-561, 1966.

[28] I. Barash and E. Angel, "Isolation and properties of exopolygalacturonase produced by Penicillium digitatum during infection of lemon fruits," Israel Journal Of Botany, vol. 19, pp. 599608, 1970.

[29] A. S. Trescott and J. Tampion, "Properties of the endopolygalacturonase secreted by Rhizopus stolonifer," Journal of General Microbiology, vol. 80, no. 2, pp. 401-409, 1974.

[30] N. G. Nabi, M. Asgher, A. H. Shah, M. A. Sheikh, and M. J. Asad, "Production of pectinase by Trichoderma harzianum in solid state fermentation of Citrus peel," Pakistan Journal of Agricultural Sciences, vol. 40, no. 3-4, pp. 193-201, 2003.

[31] A. Tsereteli, L. Daushvili, T. Buachidze, E. Kvesitadze, and N. Butskhrikidze, "Production of pectolytic enzymes by microscopic fungi Mucor sp. 7 and Monilia sp. 10," Bulletin of the Georgian National Academy of Sciences, vol. 3, no. 2, pp. 126-129, 2009.

[32] E. Gomes, R. S. R. Leite, R. Da Silva, and D. Silva, "Purification of an exopolygalacturonase from Penicillium viridicatum RFC3 produced in submerged fermentation," International Journal of Microbiology, vol. 2009, Article ID 631942, 8 pages, 2009.

[33] J. C. Esquivel and C. E. Voget, "Purification and partial characterization of an acidic polygalacturonase from Aspergillus kawachii," Journal of Biotechnology, vol. 110, no. 1, pp. 21-28, 2004.

[34] S. A. Mohamed, T. M. I. E. Christensen, and J. D. Mikkelsen, "New polygalacturonases from Trichoderma reesei: characterization and their specificities to partially methylated and acetylated pectins," Carbohydrate Research, vol. 338, no. 6, pp. 515-524, 2003.

[35] S. M. C. Celestino, S. Maria de Freitas, F. Javier Medrano, M. Valle de Sousa, and E. X. F. Filho, "Purification and characterization of a novel pectinase from Acrophialophora nainiana with emphasis on its physicochemical properties," Journal of Biotechnology, vol. 123, no. 1, pp. 33-42, 2006.

[36] N. Saad, M. Briand, C. Gardarin, Y. Briand, and P. Michaud, "Production, purification and characterization of an endopolygalacturonase from Mucor rouxii NRRL 1894," Enzyme and Microbial Technology, vol. 41, no. 6-7, pp. 800805, 2007.

[37] P. N. Shastri, M. Patil, and N. V. Shastri, "Production, purification and properties of Geotrichum candidum polygalacturonase: regulation of production by pyruvate," Indian Journal of Biochemistry and Biophysics, vol. 25, no. 4, pp. 331335, 1988.

[38] C. Yao, W. S. Conway, and C. E. Sams, "Purification and characterization of a polygalacturonase produced by Penicillium expansum in apple fruit," Phytopathology, vol. 86, no. 11, pp. 1160-1166, 1996.

[39] L. K. Huang and R. R. Mahoney, "Purification and characterization of an endo-polygalacturonase from Verticillium alboatrum," Journal of Applied Microbiology, vol. 86, no. 1, pp. 145156, 1999.

[40] B. D. Bruton, Z. X. Zhang, and M. E. Miller, "Fusarium sp. causing cantaloupe fruit rot in the lower rio grande valley of Texas," in Annals Research Report of Texas AgriLife Extension Service, pp. 17-24, Texas AgriLife Extension Service, Weslaco, Tex, USA, 1998. 
[41] S. K. Niture and A. Pant, "Purification and biochemical characterization of polygalacturonase II produced in semi-solid medium by a strain of Fusarium moniliforme," Microbiological Research, vol. 159, no. 3, pp. 305-314, 2004.

[42] S. A. Mohamed, N. M. Farid, E. N. Hossiny, and R. I. Bassuiny, "Biochemical characterization of an extracellular polygalacturonase from Trichoderma harzianum," Journal of Biotechnology, vol. 127, no. 1, pp. 54-64, 2006.

[43] A. Kaji and T. Okada, "Purification and properties of an unusually acid-stable endo-polygalacturonase produced by Corticium rolfsii," Archives of Biochemistry and Biophysics, vol. 131, no. 1, pp. 203-209, 1969.

[44] H. L. Kumari and M. Sirsi, "Purification and proper ties of endo polygalacturonase from Ganoderma lucidum," Journal of General Microbiology, vol. 65, pp. 285-290, 1971.

[45] A. M. Gillespie, K. Cook, and M. P. Coughlan, "Characterization of an endopolygalacturonase produced by solid-state cultures of the aerobic fungus Penicillium capsulatum," Journal of Biotechnology, vol. 13, no. 4, pp. 279-292, 1990.

[46] N. A. Shanley, L. A. M. Van Den Broek, A. G. J. Voragen, and M. P. Coughlan, "Physicochemical and catalytic properties of three endopolygalacturonases from Penicillium pinophilum," Journal of Biotechnology, vol. 28, no. 2-3, pp. 199-218, 1993.

[47] S. A. Singh and A. G. A. Rao, "A simple fractionation protocol for, and a comprehensive study of the molecular properties of, two major endopolygalacturonases from Aspergillus niger," Biotechnology and Applied Biochemistry, vol. 35, no. 2, pp. 115123, 2002.

[48] E. Bonnin, A. Le Goff, R. Körner et al., "Study of the mode of action of endopolygalacturonase from Fusarium moniliforme," Biochimica et Biophysica Acta, vol. 1526, no. 3, pp. 301-309, 2001.

[49] E. S. Martins, D. Silva, R. Da Silva, and E. Gomes, "Solid state production of thermostable pectinases from thermophilic Thermoascus aurantiacus," Process Biochemistry, vol. 37, no. 9, pp. 949-954, 2002.

[50] G. Kaur, S. Kumar, and T. Satyanarayana, "Production, characterization and application of a thermostable polygalacturonase of a thermophilic mould Sporotrichum thermophile Apinis," Bioresource Technology, vol. 94, no. 3, pp. 239-243, 2004.

[51] M. V. V. de Andrade, A. B. Delatorre, S. A. Ladeira, and M. L. L. Martins, "Production and partial characterization of alkaline polygalacturonase secreted by thermophilic Bacillus sp. SMIA-2 under submerged culture using pectin and corn steep liquor," Ciencia e Tecnologia de Alimentos, vol. 31, no. 1, pp. 204-208, 2011.

[52] C. Tari, N. Gögus, and F. Tokatli, "Optimization of biomass, pellet size and polygalacturonase production by Aspergillus sojae ATCC 20235 using response surface methodology," Enzyme and Microbial Technology, vol. 40, no. 5, pp. 11081116, 2007.

[53] G. Sathiyaraj, S. Srinivasan, H. B. Kim et al., "Screening and optimization of pectin lyase and polygalacturonase activity from ginseng pathogen Cylindrocarpon destructans," Brazilian Journal of Microbiology, vol. 42, no. 2, pp. 794-806, 2011.

[54] F. M. Rombouts and W. Pilnik, "Enzymes in fruit and vegetable juice technology," Process Biochemistry, vol. 13, pp. 9-13, 1978. 

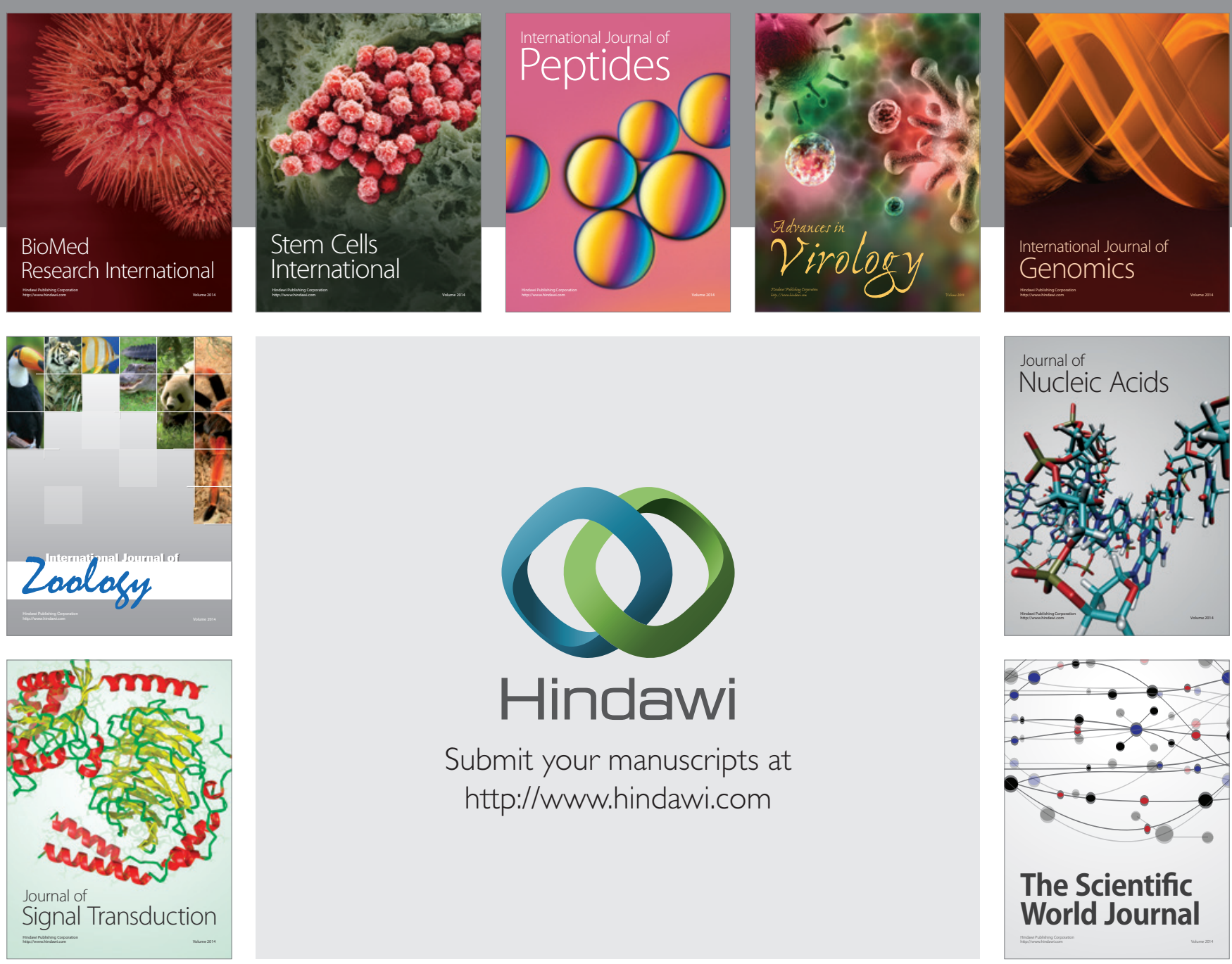

Submit your manuscripts at

http://www.hindawi.com
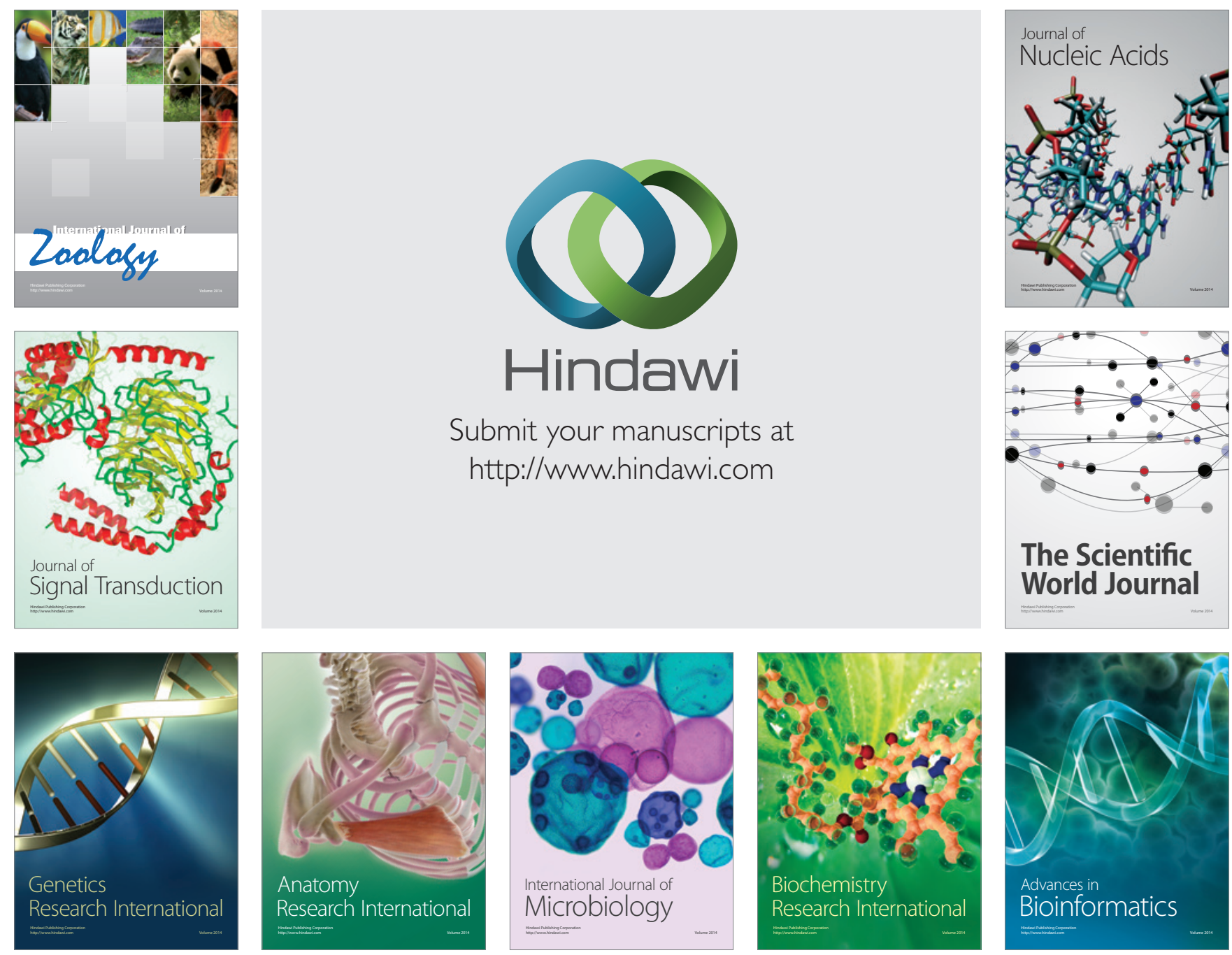

The Scientific World Journal
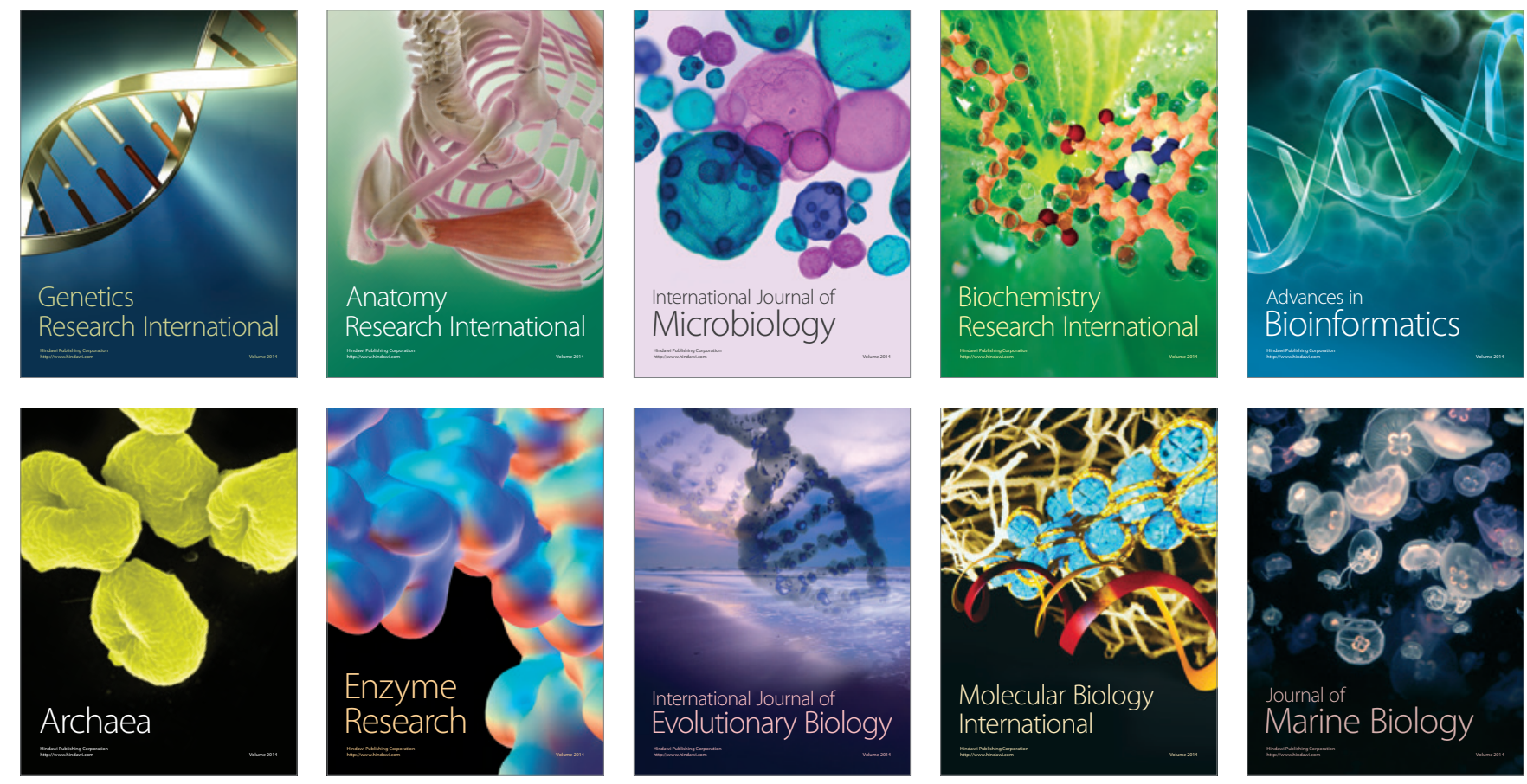